\title{
Mengatasi Dampak Negatif Diskalkulia Dalam Menyelesaikan Masalah Matematika
}

\author{
${ }^{1}$ Yenny Suzana*, ${ }^{2}$ Iyana Maulida \\ Email: yenni.suzana@gmail.com \\ Tarbiyah \& Ilmu Keguruan IAIN Langsa, Langsa, Provinsi Aceh
}

\begin{abstract}
Dyscalculia is a mathematics learning disorder in children who have difficulty counting and calculating. Children who have dyscalculia will show difficulty in doing assignments involving numbers and mathematical symbols. Children with dyscalculia are unable to digest questions and do mathematical processes, or understand abstract questions. So children with dyscalculia cannot solve math problems like children in general. So that to overcome these negative impacts, with dyscalculous disorders can more easily understand and solve math problems.
\end{abstract}

Keywords: dyscalculia, mathematica's problems, learning disorders, numeracy, mathematics

\begin{abstract}
Abstrak
Diskalkulia adalah gangguan belajar matematika pada siswa yang memiliki kesulitan dalam berhitung (counting) dan mengkalkulasi (calculating). Siswa yang mengalami diskalkulia akan menunjukkan kesulitan dalam mengerjakan tugas yang melibatkan angka maupun simbol matematika. Siswa dengan diskalkulia tidak mampu untuk mencerna soal dan melakukan proses matematika, atau memahami soal-soal yang bersifat abstrak. Jadi siswa yang mengalami diskalkulia tidak dapat menyelasaikan masalah matematika seperti siswa-siswa pada umumnya. Sehingga untuk mengatasi dampak negatif tersebut hendaklah masalah matematika yang bersifat abstrak harus divisualisasikan agar siswa dengan gangguan diskalkulia dapat lebih mudah dalam memahami dan menyelesaikan soal matematika.
\end{abstract}

Kata Kunci: diskalkulia, masalah matematika, gangguan belajar, berhitung, matematika

\footnotetext{
${ }^{*}$ Correspondence:

Email: yenni.suzana@gmail.com
} 


\section{A. PENDAHULUAN}

Setiap individu selalu mengalami perubahan. Perubahan individu merupakan manivestasi dari proses belajar. Hasil belajar adalah semua aktivitas belajar yang ditunjukkan dengan perubahan tingkah laku individu tersebut. Jadi belajar bukan sekedar suatu hasil melainkan juga suatu proses dan pengalaman dari aktivitas belajar. Oleh karena itu belajar berlangsung secara aktif dan integratif dengan menggunakan berbagai bentuk perbuatan untuk mencapai suatu perubahan ${ }^{1}$

Dalam melakssiswaan proses pembelajaran, setiap siswa tidak hanya melibatkan kemampuan fisik, akan tetapi juga melibatkan kemampuan mental secara kognitif. Kemampuan mental tersebut yang dibutuhkan siswa untuk melihat kesiapan siswa dalam aktivitas belajar. Djamarah ${ }^{2}$ mengatakan bahwa perubahan yang terjadi akibat belajar merupakan perubahan yang erat kaitannya dengan aspek mental atau kejiwaan dan dapat berpengaruh terhadap tingkah laku.

Setiap siswa mempunyai kemampuan mental yang berbeda dalam menyerap stimulus yang diperlukan sebagai proses belajar. Hal ini selaras dengan yang diungkapkan oleh Soemanto ${ }^{3}$ bahwa perbedaan tersebut terjadi sebagai akibat latar belakang hereditas dan lingkungan mereka yang berbeda pula. Selain itu, Dalyono ${ }^{4}$ berpendapat bahwa kemampuan mental yang berbeda pada tiap-tiap individual dikarenakan perbedaan operasi yang ada, baik dari sel-sel otak, alat-alat indera bahkan pada bagian-bagian lain dari sistem syaraf dalam otak.

Tiap siswa mempunyai cara belajar yang berbeda-beda, tidak semua mampu menangkap pelajaran dengan baik, beberapa dari mereka ada yang merasa susah untuk menangkap pelajaran dan sebagian yang lain dapat dengan mudahnya menerima apa yang dipelajari. Hal tesebut sering ditemui pada tiap siswa dalam aktivitas belajar. Dengan adanya perbedaan aktivitas belajar, menyebabkan terjadinya perbedaan tingkah laku tiap siswa. Siswa yang susah melakssiswaan aktivitas belajar inilah disebut dengan kesulitan belajar. Djamarah ${ }^{5}$ berasumsi bahwa masalah yang menyebabkan seseorang mengalami kesulitan dalam belajar dapat berupa sindrom psikologis yaitu berupa ketidakmampuan belajar (learning disability).

Kesulitan belajar merupakan kekurangan yang tidak nampak secara lahiriah. Ketidakmampuan dalam belajar tidak dapat dikenali dalam wujud fisik yang berbeda dengan orang yang tidak mengalami masalah kesulitan belajar. Kesulitan belajar ini tidak selalu disebabkan karena faktor intelligensi yang rendah (kelainan mental), akan tetapi dapat juga disebabkan karena faktor lain di luar intelligensi.

Salah satu faktor yang dapat menentukan proses belajar siswa ialah perbedaan individual siswa itu sendiri. Secara umum, gangguan belajar tiap siswa sebenarnya tidak terlalu terlihat secara signifikan, apabila siswa itu sendiri dapat mengikuti pelajaran dengan baik. Akan tetapi lain halnya jika kemampuan siswa diakibatkan oleh beberapa faktor yang berkaitan dengan ketidakmampuan belajar

\footnotetext{
${ }^{1}$ Soemanto, Psikologi Pendidikan (Jakarta: Rineka Cipta, 1998)

${ }^{2}$ Djamarah, Syaiful Bahri. Psikologi Belajar (Jakarta: PT. Rineka Cipta, 2002)

${ }^{3}$ Soemanto, Op. Cit

${ }^{4}$ Dalyono, Psikologi Pendidikan (Jakarta: Rineka Cipta, 2001)

${ }^{5}$ Djamarah, Op. Cit
} 
(learning disability) yang disebabkan oleh faktor sindrom psikologis. Djamarah ${ }^{6}$ menegaskan bahwa sindrom psikologis merupakan kesulitan belajar (learning disability) yang menunjukkan adanya masalah yang muncul sebagai indikator keabnormalan psikis sehingga menimbulkan gangguan belajar pada siswa. Salah satu sindrom psikologis yang mengganggu aktivitas belajar dikenal dengan sebutan diskalkulia.

Diskalkulia merupakan suatu ketidakmampuan belajar (learning disability) dengan salah satu cirinya yaitu kekacauan dalam berhitung. Menurut Haris dan Munawir $^{7}$ diskalkulia ialah ketidakmampuan berhitung yang penyebabnya gangguan pada sistem saraf pusat. Ketidakmampuan berhitung akibat gangguan sistem saraf yang dimaksud adalah siswa lemah pada kemampuan persepsi sosial, juga lemah terhadap konsep arah dan waktu, serta terkena gangguan memori. Begitu pula siswa yang mengalami kesulitan dalam membedakan bentuk geometrik, simbolik, konsep angka, bahkan kesulitan dalam melakukan operasi matematika seperti operasi penjumlahan, pengurangan, perkalian serta pembagian dengan mahir.

Suatu situasi yang menyebabkan siswa sulit dalam membedakan bentuk geometrik, simbolik serta melakukan proses operasi hitung merupakan masalah bagi individu tersebut. Bell " $A$ situation is a problem for person if he or she is aware of its existance, recognize that it requires action, wants or needs to act and does so, and is not immediately able to resolve the situation”. Bell menegaskan bahwa suatu situasi merupakan masalah bagi seseorang jika ia sadar akan adanya, mengetahui bahwa perlu tindakan, ingin atau butuh bertindak dan melakukannya, dan tidak dengan segera dapat menyelesaikan situasi tersebut. Siswono ${ }^{9}$ mengartikan masalah sebagai suatu situasi atau pertanyaan yang dihadapi individu atau kelompok ketika mereka tidak mempunyai aturan, algoritma atau prosedur tertentu atau hukum yang segera dapat digunakan untuk menentukan jawabannya.

Situasi yang dimaksud pada definisi sebelumnya dalam matematika merupakan masalah matematika yang berupa soal ataupun pertanyaan-pertanyaan. Hudojo ${ }^{10}$ mengatakan suatu pertanyaan merupakan suatu masalah jika seseorang tidak mempunyai aturan atau hukum tertentu yang segera dapat digunakan untuk menemukan jawaban dari pertanyaan tersebut. Jadi masalah matematika pada umumnya berbentuk soal matematika, namun tidak semua soal matematika merupakan masalah. Bentuk soal merupakan salah satu dasar dalam menentukan jenis-jenis masalah dalam matematika. Perlu diketahui bahwa suatu pertanyaan merupakan suatu masalah bergantung pada waktu. Ini disebabkan apabila suatu pertanyaan merupakan masalah bagi siswa pada saat ini, namun bukan merupakan masalah bagi siswa tersebut dikemudian, jika siswa tersebut telah mengetahui

\footnotetext{
${ }^{6}$ Ibid 5

${ }^{7}$ Haris Mudjiman dan Munawir Yusuf (Ed). Disfungsi Minimal Otk (DMO) dan Kesulitan Belajar Siswa. (Surakarta: Pusat Penelitian UNS, 1990)

${ }^{8}$ Bell, Frederick H. Teaching and Learning Mathematics. (USA: Wm C. Brown Publisher, 1978)

9 Siswono, Tatag Y. E. Model Pembelajaran Matematika berbasis Pengajuan dan Pemecahan Masalah Untuk Meningkatkan Kemampuan Berpikir Kreatif. (Surabaya: Unesa university press, 2008)

${ }^{10}$ Hudojo. Belajar Mengajar Matematika. (Jakarta: P2LPTK Depdikbud, 2001), hlm. 162
} 
cara, proses ataupun strategi yang digunakan untuk menyelesaiakan masalah tersebut.

Diskalkulia merupakan kesulitan belajar dalam berhitung padahal keterampilan berhitung merupakan salah satu dasar dalam menyelesaikan masalah dalam matematika dan merupakan sarana yang penting untuk menguasai bidang studi lainnya. Lebih lanjut dalam artikel ini akan dibahas permasalahanpermasalahan tentang diskalkulia, serta bagaimana mengatasi dampak negatif diskalkulia dalam menyelesaikan masalah matematika.

\section{Pengertian Diskalkulia}

Dyscalculia berasal dari bahasa Yunani yang berarti "ketidakmampuan berhitung". Awalan "dys" berarti "ketidakmampuan" sedangkan "calculus" berarti "kerikil", manik, dekak atau kelereng. Karena zaman dahulu menghitung dengan alat bantu kerikil maka dari sinilah istilah diskalkulia berasal.

Diskalkulia merupakan suatu ketidakmampuan belajar (learning disability) dengan salah satu cirinya yaitu kekacauan dalam berhitung. Menurut Haris dan Munawir ${ }^{11}$ diskalkulia ialah ketidakmampuan berhitung yang penyebabnya gangguan pada sistem saraf pusat. Ketidakmampuan berhitung akibat gangguan sistem saraf yang dimaksud adalah siswa lemah pada kemampuan persepsi sosial, juga lemah terhadap konsep arah dan waktu, serta terkena gangguan memori. Begitu pula siswa yang mengalami kesulitan dalam membedakan bentuk geometrik, simbolik, konsep angka, bahkan kesulitan dalam melakukan operasi matematika seperti operasi penjumlahan, pengurangan, perkalian serta pembagian dengan mahir.

Jacinta F. Rini, dari Harmawan consulting, Jakarta (Tabloid Nakita), mengungkapkan bahwa diskalkulia disebut juga dengan "math difficulty", sebab berkaitan dengan gangguan pada kemampuan berhitung secara matematis. Ketidakmampuan ini dapat dilihat secara kuantitatif yang terbagi menjadi bentuk ketidakmampuan berhitung (counting) juga ketidakmampuan mengkalkulasi (calculate). Siswa yang terkena gangguan ini akan menunjukkan ketidakmampuan dalam memahami proses-proses terkait matematis. Hal tersebut diketahui dengan munculnya kesulitan belajar dan menyelesaikan tugas yang bersangkutan dengan simbol matematis maupun angka.

Nevid mengatakan jika siswa mendapatkan masalah matematik dengan tingkat yang serius, maka siswa tersebut bisa dikategorikan mengalami masalah diskalkulia. Masalah yang dimaksud yaitu masalah dalam memahami istilahistilah pada matematika dasar atau operasi matematika seperti operasi dalam penjumlahan, pengurangan, perkalian hingga pembagian, bahkan beberapa siswa tidak memahami simbol-simbol matematika, dan atau tabel perkalian sekalipun. Masalah tersebut biasanya terlihat sejak usia 8 tahun. Akan tetapi untuk beberapa kasus, ada yang sudah terlihat sejak mereka usia 6 tahun bahkan sampai usia 10 tahun. Sementara Sylvia Farnham-Diggory ${ }^{12}$ membatasi diskalkulia hanya suatu gejala kesulitan dalam mengoperasikan aritmatika.

${ }^{11}$ Haris Mudjiman dan Munawir Yusuf (Ed). Disfungsi Minimal Otk (DMO) dan Kesulitan Belajar Siswa. (Surakarta: Pusat Penelitian UNS, 1990) 1994)

${ }^{12}$ Farnham. The Learning Disabled Child. (London, England: Hardvard University Press, 
Akan tetapi sampai sekarang tidak ada satu definisi khusus yang diterima secara luas mengenai diskalkulia.

\section{Tipe-Tipe Diskalkulia}

Sylvia Farnham-Diggory ${ }^{13}$ mengemukakan ada 4 tipe gangguan diskalkulia, diantaranya yaitu: tipe 1 (lemah dalam logika), tipe 2 (lemah dalam perencanaan), tipe 3 (tekun dalam tugas), dan tipe 4 (ketidakmampuan untuk menghitung sederhana).

1) Tipe 1: Lemah dalam logika

Siswa tidak mampu untuk menjelaskan tentang suatu bentuk dan ukuran.

Misalnya ia tidak mampu membedakan ukuran dan sulit menjelaskan ukuran segitiga (panjang, lebar). Kelemahan dibidang logika ini juga ditunjukkan pada waktu siswa menulis 1029 dengan 129 atau kadang menulis 1029 dengan 100029 (sesuai dengan ucapan: seribu dua puluh sembilan), tanpa memperhatikan bentuk hubungan yang signifikan. Siswa juga sering kesulitan dalam melihat kalender dan jam. Siswa kesulitan dalam menulis dan menggambar angka. Ia tidak dapat menghitung $389 \times 68$. Ia juga tidak mampu menuliskan atau menggambar porogapit dengan benar.

2) Tipe 2: Lemah dalam perencanaan

Kasus dalam tipe ini yaitu siswa tidak mampu untuk menganalisa suatu masalah yang sederhana, sehingga mengaakibatkan siswa kesulitan dalam memecahkan masalah.

3) Tipe 3: Tekun dalam tugas

Siswa dapat menunjukkan ketekunannya dalam menyelesaikan masalah namun apa yang dikerjakannya tidak pernah benar atau dengan kata lain selalu salah.

4) Tipe 4: Ketidakmampuan menghitung sederhana

Siswa kesulitan dalam menjumlahkan, mengurangkan, mengalikan serta membagi dalam menyelesaikan soal-soal sederhana. Contohnya: dalam menjumlahkan soal $27+18=\ldots$, dikerjakan sebagai berikut:

$$
\begin{aligned}
& 27 \\
& 18+ \\
& \hline 315
\end{aligned}
$$

Cara yang digunakan siswa dalam menyelesaikan soal di atas sebagai berikut: $2+1=3$, setelah itu menjumlahkan $7+8=15$, sehingga didapat 315 .

\section{Karakteristik Diskalkulia}

Lerner menjelaskan ${ }^{14}$ bahwa ada beberapa ciri-ciri siswa yang mengalami gangguan diskalkulia, diantaranya:

1) Adanya gangguan dalam memahami pola hubungan keruangan

Konsep pola hubungan keruangan yang dimaksud seperti "atasbawah, puncak-dasar, jauh-dekat, tinggi-rendah, depan-belakang, awalakhir" biasanya sudah mampu dikuasai oleh siswa jauh ketika mereka belum masuk Sekolah Dasar (SD). Beberapa siswa mendapatkan pemahaman

\footnotetext{
${ }^{13}$ Ibid 12

${ }^{14}$ Lerner. Learning Disabilities: Theories, diagnosis, and Teaching Strategies (Boston, Hounghton Mifflin, 1981), hlm. 35
} 
konsep pola hubungan keruangan tersebut dari pengalaman siswa itu sendiri dalam berkomunikasi dengan lingkup sosial mereka, ataupun dari permainan yang pernah mereka mainkan sebelumnya. Namun siswa tersebut tidak mampu belajar disebabkan oleh faktor kesulitan dalam berkomunikasi, dan lingkup sosialnya tidak mendukung kondisi yang kondusif agar terjalin komunikasi antar mereka.

Ada dua kondisi penyebab siswa mengalami gangguan dalam memahami beberapa konsep pola hubungan keruangan, diantaranya kondisi instrinsik yang ada karena ketidakmampuan otak dan kondisi ekstrinsik berupa lingkup sosial yang tidak mendukung adanya komunikasi. Memiliki gangguan dalam memahami konsep-konsep pola hubungan keruangan bisa menyulitkan pemahaman siswa mengenai sistem bilangan secara keseluruhan. Sebab adanya gangguan tersebut, siswa tidak bisa merasakan jarak tiap angka pada garis bilangan atau penggaris, sehingga siswa juga tidak mengetahui bahwa angka 4 ternyata lebih dekat ke angka 5 daripada ke angka 7.

2) Abnormalitas persepsi visual

Siswa diskalkulia sering mengalami ketidakmampuan melihat macammacam objek dalam satu kelompok dan hubungan diantaranya. Hal tersebut dapat terjadi dikarenakan adanya gejala abnormalitas persepsi visual. Kemampuan melihat macam-macam objek dalam suatu kelompok adalah dasar yang penting sehingga siswa dapat secara cepat dan tepat dalam menentukan jumlah objek dalam suatu kelompok.

Siswa yang mengalami abnormalitas persepsi visual akan terlihat tidak mampu bila mereka disuruh untuk menjumlahkan dua kelompok benda yang masing-masing benda tersebut terdiri dari empat atau lima anggota. Siswa dengan masalah tersebut akan menghitung anggota benda tersebut satu persatu terlebih dahulu sebelum kemudian menjumlahkannya.

3) Asosiasi visual-motorik

Siswa diskalkulia juga tidak mampu menghitung beberapa benda dengan berurutan sambil membilang benda tersebut, seperti "satu, dua, tiga, ...". Akan tetapi siswa baru memegang benda kedua namun baru mengucapkan "satu" atau kebalikannya baru menyentuh benda pertama namun ia sudah mengucapkan "dua". Siswa dengan masalah tersebut menunjukkan kesan bahwa ia hanya menghafal bilangan tapi tidak memahami maknanya.

4) Perseverasi

Beberapa siswa ada yang perhatiannya fokus pada satu objek saja dengan waktu yang lama. Gangguan perhatian seperti itu dikenal dengan perseverasi. Dimana siswa tersebut awalnya dapat menyelesaikan tugas dengan baik, namun lambat laun fokusnya melekat pada objek yang lain.

5) Ketidakmampuan dalam mengenal dan memahami simbol

Sebagian siswa diskalkulia yang mengalami ketidakmampuan dalam mengenal dan menggunakan beberapa simbol matematika, seperti :,,$+- \times, \div$, $>$, < dan simbol lainnya. Ketidakmampuan dalam masalah ini dikarenakan adanya gangguan memori pada otak atau bisa juga disebabkan adanya gangguan persepsi visual. 
6) Gangguan penghayatan tubuh

Siswa dengan masalah diskalkulia juga sering menunjukkan adanya gangguan penghayatan tubuh (body image). Siswa yang mengalami masalah ini akan merasa sukar untuk memahami hubungan dari bagian-bagian tubuhnya sendiri. Misalnya siswa disuruh untuk menggambar bagian tubuh manusia, maka yang ia lakukan adalah menggambar dengan beberapa bagian yang tidak lengkap atau menempatkan bagian tubuh pada posisi yang tidak tepat. Contohnya: tangan diletakkan di kaki, atau bagian mata yang diletakkan pada bagian hidung, dan sebagainya.

7) Kesulitan memahami bahasa dan membaca

Pelajaran matematika merupakan pelajaran yang banyak menggunakan simbol-simbol tertentu. oleh sebab itu, kesulitan dalam memahami bahasa bisa mempengaruhi kemampuan siswa pada pelajaran ini. Soal matematika yang didesain berbentuk soal cerita menuntut kemampuan membaca untuk menyelesaikannya. Sehingga siswa yang mengalami kesulitan memahami bahasa dan membaca akan susah untuk menyelesaikan soal tersebut.

8) Performance IQ lebih rendah daripada Verbal IQ

Hasil tes inteligensi dengan mengandalkan alat WISC membuktikan bahwa siswa diskalkulia memiliki skor Performance IQ (PIQ) yang lebih rendah daripada skor Verbal IQ (VIQ). Tes inteligensi tersebut mempunyai dua kategori sub tes, diantaranya tes performance dan tes verbal. Sub tes performance mencakup: melengkapi objek, menyusun objek, menyusun gambar, menyusun balok dan coding. Sementara sub tes verbal meliputi: Informasi, persamaan, aritmatika, bendahara kata, serta pemahaman. Sementara.

Rendahnya skor PIQ yang dialami oleh siswa diskalkulia ini berkaitan dengan kesulitan dalam memahami konsep keruangan, gangguan persepsi visual, dan juga adanya gangguan asosisasi visual-motorik.

Untuk membantu siswa yang sulit belajar matematika, guru harus paham macam-macam kesalahan umum yang dikerjakan siswa dalam menyelesaikan soal-soal matematika. Lerner ${ }^{15}$ menegaskan bahwa kesalahan tersebut meliputi: kurangnya pemahaman mengenai simbol, kurangnya pemahaman mengenai nilai tempat, kurangnya pemahaman tentang perhitungan, menggunakan proses yang salah, hingga tulisan yang tidak dapat dibaca.

1) Kurangnya pemahaman mengenai simbol

Siswa-siswa biasanya tidak banyak mengalami kesulitan jika diberikan latihan seperti $3+4=\ldots$, atau $5-3=\ldots$ Sebaliknya akan sulit jika dihadapkan pada latihan soal seperti $3+\ldots=5 ; 6=\ldots .+2 ; \ldots+4=8$; atau $7-\ldots=5$. Ketidakmampuan seperti ini biasanya disebabkan siswa tidak paham simbol-simbol, seperti: $=,+,-$ dan sebagainya. Untuk dapat menyelesaikan soal-soal matematika, maka siswa harus terlebih dahulu paham mengenai simbol-simbol tersebut. 
2) Kurangnya pemahaman mengenai nilai tempat

Beberapa siswa ada yang belum memahami nilai tempat, seperti ratusan, puluhan bahkan satuan. Ketidakmampuan siswa mengenai nilai tempat akan menyulitkan siswa jika ia dihadapkan pada lambang bilangan basis yang bukan sepuluh. Bahkan siswa yang tidak mempunyai kesulitan belajar sekalipun, juga mengalami kesulitan dalam memahami lambang bilangan yang bukan berbasis sepuluh. Sehingga banyak pihak yang mendukung agar pelajaran matematika SD lebih difokuskan pada aritmatika atau berhitung yang sering digunakan dalam kehidupan sehari-hari.

Siswa yang melakukan kesalahan seperti hal tersebut, bisa juga disebabkan oleh kekhilafan cara menghitung masalah penjumlahan atau pengurangan yang bersusun ke bawah, sehingga siswa tidak cukup hanya diberikan pemahaman mengenai nilai tempat saja, namun akan lebih baik juga diberikan latihan-latihan yang cukup. Contohnya:
75
68
27
13
$\overline{58}^{-} \quad \overline{71}^{+}$

3) Kurangnya pemahaman tentang perhitungan

Sebagian siswa yang tidak mengenal konsep perkalian dengan baik, akan menghafal perkalian tersebut. Hal ini menyebabkan timbulmya kekeliruan jika hafalannya salah. Jika siswa sudah memahami konsep perkalian, maka daftar perkalian mungkin akan membantu memperbaiki kekeliruan yang dibuat siswa tersebut.

Contohnya:

$6 \quad 8$

$7 \quad 7$

$\overline{46}^{\times} \quad \frac{7}{54}^{\times}$

4) Menggunakan proses yang salah

Kekeliruan dalam menggunakan proses perhitungan yang salah dapat terjadi dikarenakan beberapa masalah sebagai berikut:

$>$ Menukarkan simbol;

$6 \quad 15$

23

$\overline{8}^{\times} \quad \frac{}{18}$

$>$ Jumlah satuan dan puluhan ditulis dengan tidak memperhatikan nilai tempat;

$\begin{array}{ll}34 & 77 \\ 78 & 38 \\ \overline{1012} & \overline{1015}^{+}\end{array}$

$>$ Semua digit dijumlahkan secara bersamaan

\begin{tabular}{ll}
51 & 63 \\
22 & 10 \\
10 & \\
\hline
\end{tabular}


Siswa menghitung sebagai berikut:

$5+1+2+2=10$

$6-3-1-0=2$

$>$ Jika menyelesaikan soal penjumlahan, siswa menggabungkan antara puluhan dengan satuan;

$\begin{array}{ll}56 & 64 \\ \overline{153}^{+} & \overline{162}^{+}\end{array}$

$>$ Bilangan dengan nilai yang besar dikurangi bilangan dengan nilai yang kecil tanpa memperhatikan nilai tempat;

$\begin{array}{ll}631 & 651 \\ 472 & 377 \\ \overline{24}^{-} & \overline{326}^{-}\end{array}$

5) Tulisan yang tidak dapat dibaca

Sebagian siswa tidak dapat membaca tulisan yang mereka buat sendiri sebab bentuk huruf yang ditulis tidak sesuai atau tidak lurus mengikuti garis. Kosekuensinya adalah siswa mengalami banyak kesalahan karena tidak dapat membaca tulisannya sendiri.

\section{Penyebab Diskalkulia}

Berret $^{16}$ mengemukakan penderita diskalkulia diperkirakan berjumlah sekitar 3-6\% dari seluruh populasi dunia dengan tingkat IQ yang berbeda-beda. Diskalkulia sering dikaitkan dengan Attention Deficit Hyperactivity Disorder (ADHD). Hal ini mengacu pada penelitian yang menunjukan seperempat dari penderita diskalkulia yang ditemui ternyata juga merupakan penderita ADHD. Sejauh ini, satu-satunya alasan mengapa diskalkulia bisa menyerang 3-6 dari 100 orang adalah faktor genetik. Hal ini pula yang membedakan diskalkulia dengan akalkulia. Akalkulia adalah ketidakmampuan seseorang dalam memproses informasi matematika dikarenakan kerusakan otak (brain injury), sedangkan diskalkulia diturunkan dari generasi ke generasi. Beberapa asumsi terkait penyebab diskalkulia diluar faktor genetika adalah kelahiran yang belum matang atau dengan kata lain lahir prematur dan juga mengkonsumsi minuman alkohol ketika hamil, namun hal ini tidak dapat dijadikan acuan yang tepat. Asumsi lain terkait penyebab diskalkulia adalah faktor psikologi, yang dapat terjadi dikarenakan trauma atau ketakutan yang luar biasa, dalam kata lain phobia terhadap pelajaran matematika yang bisa saja dikarenakan pengalaman buruk yang terjadi ketika proses pembelajaran matematika sedang berlangsung.

${ }^{16}$ Berret. Learning Disabilities 101: Everything You Need to Know how About Learning Disabilities Affext Reading Skills (Reading Horizons, 2010) 
Sudarmadji ${ }^{17}$ membagi beberapa penyebab diskalkulia sebagai berikut:

1. Lemah dalam proses penglihatan atau visual

Siswa yang mempunyai kelemahan dalam proses penglihatan akan berpeluang besar mengalami diskalkulia. Ia juga berpotensi mengalami masalah dalam mengeja serta menulis.

2. Bermasalah mengurutkan informasi

Siswa yang mengalami kelemahan mengurutkan dan mengelompokkan informasi secara lengkap, pada dasarnya akan sulit mengingat suatu fakta, konsep bahkan rumus untuk menyelesaikan perhitungan matematika. Jika masalah ini merupakan penyebabnya, maka siswa akan mengalami hambatan pada aspek bidang lainnya, misal membaca kode-kode dan mengeja, atau bahkan hal apapun yang memerlukan kemampuan pada hal mengingat secara detail.

3. Phobia terhadap pelajaran matematika

Siswa yang pernah mengalami trauma terhadap pelajaran matematika dapat kehilangan kepercayaan dirinya. Trauma juga dapat dikarenakan oleh beberapa masalah, seperti: guru yang sering marah, galak atau guru yang mempunyai wajah serta karakter yang seram. Hal tersebut membuat beberapa siswa menjadi takut bahkan mengakibatkan siswa tersebut susah memahami pelajaran matematika.

Selain masalah di atas, hal lain yang mengakibatkan siswa mengalami phobia terhadap pelajaran matematika disebabkan ketakutan siswa jika hasil yang diperoleh salah. Mereka merasa hasil dari jawaban yang salah merupakan kegagalan sehingga siswa dipaksa untuk bisa memberikan jawaban yang tepat. Padahal jawaban yang salah bukan semata suatu kegagalan saja, namun justru dapat menjadi umpan agar siswa lebih memahami konsep matematika dan dapat menganalisis pola pikirnya. Sebaiknya guru yang mengajar juga tidak langsung menghardik siswa jika jawaban yang diberikan salah, sebab tidak semua siswa dapat membangun motivasi mereka setelah mereka dihardik. Justru beberapa siswa akan semakin tertekan bahkan bisa menjadi benci terhadap pelajaran matematika.

\section{Mengatasi Dampak Negatif Diskalkulia dalam Menyelesaikan Masalah Matematika}

Meskipun diskalkulia diturunkan secara genetik, bukan berarti tidak ada hal yang bisa dilakukan untuk membantu siswa yang diskalkulia. Ada beberapa hal yang bisa dilakukan untuk membantu siswa diskalkulia dalam menyelesaiakan masalah matematika. Solusinya antara lain:

1) Matematika sering kali menjadi hal yang sangat menakutkan bagi siswa diskalkulia. Oleh sebab itu, jadikan pembelajaran matematika menjadi hal yang menarik. Seperti mengajarkan matematika menggunakan permainan seperti number bingo, flash card, dan lain-lain

2) Siswa dengan diskalkulia akan sangat sulit dalam memahami konsep matematika, oleh sebab itu, berikan masalah matematika tersebut menjadi lebih kontekstual terkait konsep yang sedang diberikan. Misalnya dengan memberikan contoh konkret menggunakan grafik dan diagram, dll.

\footnotetext{
${ }^{17}$ Sudarmadji. Mengatasi Gangguan Belajar pada Anak. (Jakarta: Prestasi Putra, 2002).
} 
3) Biarkan siswa mengeksplorasi diri mereka. Ajarkan perhitungan mudah dengan menggunakan jari, kertas scratch, atau alat peraga lain yang mudah digunakan dan mudah ditemui. Beri kesempatan mereka untuk dapat memanipulasi benda-benda konkrit. Jangan memaksa siswa untuk menghafal karena hal ini akan memperburuk keadaannya.

4) Membantu siswa memvisualisasikan tiap simbol-simbol dengan memanipulasi tanda. Misalkan minus memilki tanda (-), memiliki arti hilang. Sedangkan plus (+) artinya datang, sehingga jumlahnya menjadi banyak. Memanipulasi tanda akan sangat membantu siswa diskalkulia dalam proses perhitungan sebab dengan cara ini mereka akan paham akan arti dari setiap tanda serta membuat mereka terhindar dari penggunaan istilah matematika yang rumit.

5) Gunakan pensil warna yang berbeda untuk menggambarkan setiap masalah. Seperti misalnya menggunakan warna merah untuk tanda minus (-), hijau untuk tanda plus (+), dan lain-lain. Hal ini akan membantu siswa dalam mengartikan simbol agar tidak rancu.

6) Putarlah musik ketika proses pembelajaran sedang berlangsung. Musik dapat membantu beberapa siswa diskalkulia agar merasa tenang selama belajar. Musik juga bisa menghindari siswa dari kondisi yang tertekan.

7) Pembelajaran dilaksanakan secara teratur dan bertahap. Tidak harus terlalu memaksa hingga memberikan suatu target yang tinggi kepada siswa yang mengalami masalah diskalkulia. Berikan kepercayaan kepada siswa agar mereka dapat mengembangkan dirinya

8) Jadilah sahabat mereka yang siap mendampingi mereka dalam melewati kesulitan-kesulitan tersebut.

\section{E. KESIMPULAN}

Diskalkulia merupakan ketidakmampuan siswa dalam hal berhitung yang dipengaruhi oleh gangguan pada sistem saraf pusat. Siswa mengalami kesulitan dalam membedakan bentuk geometrik, simbolik, konsep angka, sulit mengoperasi penjumlahan, pengurangan, perkalian dan pembagian secara cepat. Karakteristik siswa penderita diskalkulia tampak dari adanya gangguan dalam hubungan keruangan, abnormalitas persepsi visual, asosiasi visual-motorik, perseverasi, kesulitan mengenal dan memahami simbol, Gangguan penghayatan tubuh, Kesulitan dalam bahasa

Mengatasi dampak negatif pada siswa diskalkulia dalam menyelesaikan masalah matematika adalah menciptakan pembelajaran matematika menjadi hal yang menarik, membuat masalah matematika tersebut lebih kontekstual, beri kesempatan untuk dapat memanipulasi benda-benda konkrit, memvisualisasi setiap simbol-simbol, lakukan secara teratur kontinyu, dan bertahap, ciptakan kondisi menyenangkan jauh dari tekanan, dan jadilah sahabat yang siap mendampingi mereka.

Beberapa hal yang perlu disarankan peneliti adalah:

1) Diharapkan kepada kepala sekolah dan guru untuk lebih memperhatikan masalah siswa dalam ketidakmampuannya menghitung matematika.

2) Guru matematika hendaknya berupaya membuat pembelajaran matematika menjadi menarik bagi siswa. Beri kesempatan pada siswa 
agar dapat memanipulasi benda-benda konkrit, memvisualisasi setiap simbol-simbol, lakukan secara teratur kontinyu, dan bertahap, ciptakan kondisi menyenangkan jauh dari tekanan, dan jadilah sahabat yang siap mendampingi mereka.

3) Para siswa hendaknya lebih semangat dan bekerja keras dalam memanipulasi benda-benda konkrit, memvisualisasi setiap simbolsimbol, lakukan secara teratur kontinyu, dan bertahap, ciptakan kondisi menyenangkan jauh dari tekanan, dan jadilah sahabat yang siap mendampingi mereka.

\section{DAFTAR PUSTAKA}

Berrett, S., "Learning Disabilities 101: Everything you need to know about how learning disabilities affect reading skills," Reading Horizons, http://www.readinghorizons.com/documents/lde-bookrh.pdf, 2010. (diakses pada 30/10/2016).

Dalyono, M, Psikologi Pendidikan. Jakarta: Rineka Cipta, 2001.

Djamarah, Syaiful Bahri, Psikologi Belajar. Jakarta: PT. Rineka Cipta, 2002.

Dyscalculia," Learning Dissabilities Association of America, http://ldaamerica.org/types-of-learning-disabilities/dyscalculia/(diakses pada 30/10/2016).

Farnham, S Diggory, The Learning Disabled Child. London, England: Hardvard University Press, 1994.

Haris Mudjiman dan Munawir Yusuf (Ed), Disfungsi Minimal Otk (DMO) dan kesulitan belajar siswa. Surakarta: Pusat Penelitian UNS, 1990.

Lerner, J.W, Learning disabilities: Theories, diagnosis, dan teaching strategies. Boston, Houghton Mifflin, 1981.

Nevid, J. S., Rathus, S. A., \& Greene, B, Psikologi Abnormal. Jakarta: Erlangga, 2003.

Rini, Jacinta F, http://www.tabloid-nakita.com/Panduan/panduan05233-02 .html. 2010. (diakses pada 29/10/2016). .

Soemanto, Wasty, Psikologi Pendidikan. Jakarta: Rineka Cipta, 1998.

Sudarmadji, Mengatasi Gangguan Belajar pada Siswa. Jakarta: Prestasi Putra, 2002.

Wikipedia. Tersedia di: https://en.wikipedia.org/wiki/Dyscalculia. (diakses pada 29/10/2016). 